\title{
Commemorative Practices in the Humanities around $1900^{*}$
}

\author{
Jo Tollebeek \\ Faculty of Arts, University of Leuven, Leuven, Belgium \\ Email: Jo.Tollebeek@arts.kuleuven.be
}

Received 27 May 2015; accepted 27 June 2015; published 30 June 2015

Copyright (C) 2015 by author and Scientific Research Publishing Inc.

This work is licensed under the Creative Commons Attribution International License (CC BY).

http://creativecommons.org/licenses/by/4.0/

c) (†) Open Access

\begin{abstract}
Around 1900, the humanities underwent a metamorphosis which led to the emergence of modern disciplines. This transformation was accompanied by another process, the building of scientific communities. The central question addressed in this essay was how these new disciplinary communities in the humanities were strengthened by commemorative practices. Those practices could be highly diverse, ranging from the dedication of a book and the circulation and collection of photographs to the organisation of tribute events, attending of funerals and writing of obituaries. The forms that these practices could take were mapped out in this essay using material drawn from the archives of three prominent (literary) historians from Belgium and the Netherlands: Paul Fredericq, Robert Fruin and Jan te Winkel.
\end{abstract}

\section{Keywords}

Discipline-Formation, Community-Building, Collective Memory, Commemorative Practices, Academic Remembrance Culture

\section{Introduction}

The practitioners of the humanities today are still striving to fulfil the role acquired by their disciplines in the

\footnotetext{
"A first draft of this article was presented at the workshop 'Disciplining Mind and Body: Virtues and Practices of the Modern Humanities', Roskilde University (Denmark), 14 September 2012. I would especially like to thank Kasper Risbjerg Eskildsen. This essay is based largely on archive material: The Paul Fredericq archive is located in the University Library in Ghent (Belgium), in the Department of Manuscripts and Valuable Works. Among its collection, the archive contains a number of diaries and memoirs, travelogues, notes on academic staff, correspondence and photographs. For a detailed list, see Tollebeek (2008). The Robert Fruin archive is located in Leiden University Library (The Netherlands), in the Special Collections department (in particular BPL 1555-1559 and BPL 2378). Among other things it contains all manner of loose notes for articles and correspondence. See Tollebeek (2010). The Jan te Winkel archive is located in the national Royal Library of the Netherlands $(\mathrm{KB})$ in The Hague. It is a very rich archive, with more than 12,000 incoming letters, copy books for outgoing correspondence, lecture notes, manuscripts of lectures and publications, diaries, congratulatory cards, photographs, etc. This material is the central focus in Tollebeek (2011).
} 
course of the nineteenth century. The aim of history and archaeology, art history and musicology, literary studies and philology, and philosophy and theology - the varied landscape of which the humanities are composed - is, just as it used to be, to open up and transmit culture. The humanities, Collini has written, "embrace that collection of disciplines which attempt to understand, across barriers of time and culture, the actions and creations of other human beings considered as bearers of meaning, where the emphasis tends to fall on matters to do with individual or cultural distinctiveness and not on matters which are primarily susceptible to characterization in purely statistical or biological terms" (Collini, 2012: p. 64).

The modern, scientific disciplines to which Collini refers and which even today still largely determine the way in which research and teaching are divided up in the humanities, originated in the decades around 1900. At that time, a process of discipline-building occurred in which the existing intellectual traditions underwent a metamorphosis ${ }^{1}$. It is this process that forms the framework for the central subject of this essay: the culture of commemoration and remembrance that emerged in the humanities as elsewhere around 1900, which is to play an essential role in the formation of the discipline.

What primarily made history, art history, literary science and the other humanities disciplines, was - apart from their substantive area of focus, often defined in manuals - the "scientific principle" that they embraced: methodological diligence, striving for objectivity, and cautiousness about the forming of judgements. Linked to these things, the process of discipline-building was, secondly, also a matter of behavioural codes, of introducing and maintaining certain standards and values. Self-control and self-denial—essential for the incessant quest for the truth that the new disciplines required in their self-representation-became cardinal among these epistemic virtues. "Science", as one neat formulation, had it a few years ago, "was no longer the rule of reason but the triumph of the will" (Daston \& Gallison, 2010: pp. 228-229). A third element in the process of discipline-formation was the creation of an institutional foundation: the humanities "academised" towards the end of the nineteenth century, becoming the preserve of professionals who were usually attached to the universities, which increasingly developed into research institutions. Thus, the humanities also became disciplines with people, objects, concepts, research directions and methods, institutes, journals and so on (Abma, 2011: pp. 28-29). The natural sciences often served as a model in all this.

But discipline-building cannot be said to have proceeded easily in the humanities around 1900. Various factors impeded the process, which as a result also assumed a form different from that in the natural sciences. The lack of a recognisable theoretical project — such as an ambitious positivism-among a majority of practitioners of the humanities was one of these factors. Nor could a universally shared methodological creed always be pointed to, while most historians could still unite behind a number of methodological slogans ("let the sources speak"), an open conflict of schools of thought occurred in literary studies. Moreover, no academic monopoly could be said to exist in the humanities (the same was true in the social sciences); on the contrary, the authority of the university professionals came under constant challenge. Finally, debate also continued about the intellectual and moral values commonly applied in the discipline: prudence and self-discipline could also be dismissed as mediocrity and lack of character.

Did these obstacles lead to failure, to "weak" disciplines whose difficult genesis proved how much they were historical constructs rather than natural phenomena? Such a judgement disregards the flexibility of disciplines, and not only in the humanities, but also in the "strong" natural sciences (Wegener, 2011). There was the additional consideration that the study of, for example, (national) history and literature could become and remain autonomous disciplines with their own distinctive flavours because there was also widespread support for them in society (see Johannes, 2011). But flexibility and social support were of course not sufficient to ensure continuity. The "imposition of discipline" was also necessary, the imprinting of the "scientific principle" and of scientific ethics and etiquette. That in turn implied socialisation of anyone wishing to gain entry to the discipline, something that in the humanities would take place in the privacy of the professor's home until well into the twentieth century.

Discipline-building was thus invariably also a question of community-building: the new discipline had to be carried forward by a group whose members - to a certain extent at least-accepted the discipline's "scientific principle", underwrote its ethics and etiquette, and supported its professional organisation and institutional structure. Around 1900, such disciplinary communities were still small and simple in the humanities, but their scale was increasing (just as their outlook was also becoming more international), which made communitybuilding all the more important: as communities grew, so too must their sense of mutual belonging. Moreover,

${ }^{1}$ For a global history of the humanities, see Bod (2010). An English edition is forthcoming. 
the fact that discipline-building largely took place in an academic context made the possession of a shared culture even more important. After all, the university itself was more than a "combination of education and research, and perhaps the provision of services to society"; primarily, it was to be understood as a living community, a "community of people with their own system of norms and values" (Van Berkel, 2009: pp. 15, 17).

Community-building was a question of inclusion and exclusion: who did and did not belong to the community? It implied the drawing of boundaries with the rest of the scientific world. But the community could also be threatened from within, for the "imposition of discipline" to which the community's members were "subject" could fail: the intellectual and moral values on which the discipline was founded could be rent asunder by "undisciplined" behaviour, by disorderliness and laziness for example, or by (what was perceived as) improper behaviour, including sexual impropriety ${ }^{2}$. Like any other history, the history of the humanities had its hidden side.

This essay explores the complex history of the humanities in the late nineteenth century and the early twentieth century from a perspective that has seldom received systematic historiographical attention: that of community-building. The emphasis lies on the role played by commemorative practices in that community-building, not least because of the emotional intensity they are able to impart to the disciplinary communities. To understand the significance and power of these commemorative practices, it is necessary to create a clear picture of their many forms.

\section{Commemorative Practices}

How could the disciplinary communities be strengthened? Some have pointed to the increasing importance of method and methodology in the humanities from around 1870: these became, it has been argued, the central elements in the professional training of historians, for example, and had an increasing impact on the face of their community (e.g. Torstendahl, 2010). Others have stressed the scientific spirit, which gained in proficiency in the humanities as elsewhere, and which meant that ultimately, work in that field began to look not so different in many respects from work in the natural and social sciences: what bound the members of the communities in the humanities together was the desire to understand and explain-with the principles that also prevailed elsewhere of precision in research, respect for the evidence, rigour of argumentation, clarity of presentation and so on (Collini, 2012: p. 62). Still others have described the extent to which the formation of disciplinary communities was reinforced and given direction by the organisation and needs of university teaching (see Dorsman, 2011).

All of these elements undoubtedly contributed to the formation of communities in the humanities, just as the specific character of the place where the knowledge was acquired was also able to give the disciplinary community further distinctiveness: just as chemists and physicists found their habitat in the new laboratories, so archaeologists and anthropologists took up their abode in museums and historians in archives (see Eskildsen, 2008). However, what equally contributed to this community-building process, and hence to discipline-building too, was the commemorative practices that became current in the humanities around 1900 or that were becoming more prominent at that time. They forged a collective memory, which was able to become a powerful force in the construction of a separate identity.

These commemorative practices are not an unfamiliar phenomenon to historians of science, who have for a long time investigated how medics, biologists, astronomers and other scientists in the past commemorated their great predecessors or celebrated the anniversaries of their institutes and laboratories (e.g. Abir-Am, 1998 and Abir-Am \& Elliott, 1999). The late nineteenth century has attracted particular interest in this regard: the positivist movement that had emerged around Auguste Comte made a systematic attempt to replace the commemorative calendar of rulers and saints with a calendar of "great minds", including numerous practitioners of science (Petit, 1998). Such studies have primarily considered the role that such commemorations play in the composition of science's collective memory, alongside other "cultural forms" (the expression is borrowed from Abir-Am) which shape this memory, such as museums, archives, oral histories and biographical dictionaries (Abir-Am \& Elliott, 1999: p. 27). In addition, the focus has been placed on the commemorative pomp, the often spectacular character of the commemorations and the accompanying rhetoric. The political use of commemorations has not escaped the attention of the historians of science, either: celebrating Nicolaus Copernicus or Simon Stevin was not a matter of science alone.

The term "commemorative practices" is usually reserved here for commemorations of deceased (often long deceased) persons such as Copernicus or Stevin or events from the past such as the foundation of an institute.

\footnotetext{
${ }^{2}$ See, for example, the reaction to the homosexuality of the historian Guillaume des Marez: Billen \& Boone (2011).
} 
However, it can also be interpreted in a broader sense. The term can be applied to a heterogeneous set of more or less organised and ritualised practices in which a scientific (sub)group gives some account of its identity that has emerged by an "historical" process, and of the significance of those who are regarded as the contemporary standard-bearers of that identity. From this viewpoint, the history that is at issue becomes considerably shorter, whereas the treatment of that history becomes broader and more varied than in the "traditional" commemorations, which are usually confined to anniversaries. Sure enough, the "historical" mise-en-scène and the penchant for hommages of the modern humanities could assume many different forms around 1900. Thus a flourishing academic commemorative culture emerged, usually embedded in the world of the universities (the term "academic commemorative culture" is taken from Zwick (1997)). Such a culture, incidentally, was not just characteristic of the humanities: the wide array of tributes and commemorative forms could also be found in the natural and social sciences, with its own variants in each case.

In the commemorative practices of which this memorialisation culture was formed, a process of community-building was accomplished: a community was marked out and delineated, and the group became closer-knit. That process was a dynamic one, for the disciplinary communities which it concerned were not static units which, once they had been formed, remained unchanging. On the contrary, they derived their remarkable persistence from a continual reaffirmation, a redrawing of the lines that had been traced out. This occurred to an equal degree in almost daily rituals and in specially organised events. All of these things were concrete articulations, not just of a commemorative culture, but of a commemorative community, whose members were continually addressed and mobilised (Rigney, 2011).

To provide empirical support for this, use can be made of the "dossiers" of three leading practitioners of the humanities from Belgium and the Netherlands around 1900, whose papers are sufficiently extensive and detailed to document the commemorative practices in which they figured prominently. The Belgian historian Paul Fredericq (1850-1920) was a professor at the University of Ghent. A specialist in the sixteenth-century Inquisition and its medieval predecessor, he also published a number of accounts of his travels around European universities; these were regarded as showcases of the practices emerging in the modern historical science. Fredericq's fellow-historian Robert Fruin (1823-1899), based in Leiden, was the first professor of national history in the Netherlands. He enjoyed a reputation as "the Dutch Ranke". The literary historian Jan te Winkel (1847-1927) was professor of "Middle Dutch and modern Dutch language and literature, Gothic, Anglo-Saxon and Middle High German" at the University of Amsterdam. He was the author of a monumental survey of the history of Dutch literature (De ontwikkelingsgang der Nederlandsche Letterkunde), published between 1908 and 1921. Fredericq, Fruin and Te Winkel are not treated as representatives of national-in this case Belgian and Dutchcommunities of scholars. Rather, the intention is to illustrate the development of the academic commemorative culture in the humanities on the basis of their extensive individual "dossiers"

It should be noted that there was a considerable age difference between Fruin on the one hand and Fredericq and Te Winkel on the other. Fruin belonged to a generation in the university world that came to maturity soon after 1850; he accepted his professorship in 1860. Fredericq and Te Winkel, by contrast, represented a generation that did not occupy the key academic posts until around 1890 . The commemorative practices that will be discussed here mainly developed at the time of this second generation. However, some of them had a lengthy prehistory. Françoise Waquet demonstrated several years ago that the culture of academic acknowledgments, so universal nowadays in the humanities and social sciences, and related to the practices discussed here, has roots as far back as the second half of the seventeenth century (Waquet, 2005: pp. 364-365). Even so, the intensification of the academic remembrance culture in the nineteenth-century fin de siècle was remarkable.

That intensification was primarily connected with what has just been outlined: the process of discipline formation and community building that was taking place around 1900 in the humanities could be reinforced by these commemorative practices. Whether these practices helped shape the disciplines and communities of the humanities or reflected a pre-existing identity and unity is difficult to say. In history, for example, disciplinespecific journals had emerged as early as the 1850s (the foundation of the Historische Zeitschrift in 1859 is regarded as a milestone in the development of the discipline); the contributors to these journals began to form communities - national communities in many cases - of historians (see Møller Jørgensen (2012), with further references; for the Historische Zeitschrift, see the articles in 150 Jahre Geschichtsforschung im Spiegel der Historischen Zeitschrift (2009)). But such institutional initiatives, which contributed to the formation of a coherent

\footnotetext{
${ }^{3}$ The three "dossiers" are discussed at length in Tollebeek (2008), more specifically 172-216; Tollebeek (2010), more specifically 32-37 and Tollebeek (2011), more specifically 42-51.
} 
discipline, required an "emotional validation", and it was just this that a culture of remembrance could provide. However, to reduce this commemorative culture to a mere confirmation of a pre-existing identity and unity would ignore the formative power that the commemorative practices could themselves have. They can be regarded, like the major commemorations, as "performative" statements: "statements in the sense that the philosopher John Austin used the term, in other words, statements that make something happen" (Burke, 2010: p. 106).

However, the fact that the academic culture of commemoration grew more intense at the end of the nineteenth century was also related to more general developments in science and at the hauts lieux of that science, the universities. An amplification of scale was in progress, and there was an accompanying fear that science was in danger of coming to grief due to a problem of overabundance or perhaps even overproduction. The material collected during archive tours, museum visits and archaeological campaigns was assuming disquieting proportions. Inscriptions were being deciphered, new images were being made accessible, travelogues were opening up evernew perspectives. A sense of losing a clear overview in the discipline was becoming more acute. At the same time, the universities themselves were also changing during the fin de siècle. They now had to function in a rapidly modernising world and were consequently undergoing modernisation themselves. In the process, the academics were among other things confronted with the rise of forms of popular culture that they found difficult to control and that even appeared to be affecting the old, familiar professorial style. Te Winkel argued repeatedly for the maintenance of the proper forms of etiquette in the scientific world. As early as 1874 he had noted in his diary: "We Dutchmen must leave carping at colleagues' work to the Germans." Commemorative practices could reinforce tradition and cohesion - sometimes in a festive manner-he believed.

The "dossiers" of Fredericq, Fruin and Te Winkel enable a number of commemorative practices from the remembrance culture in the humanities to be presented and their significance for community-building within the discipline to be outlined. The dedication of a book, the circulation and collection of photographs, the organisation of tribute events, the attendance of funerals and the writing of obituaries-these are the practices that will successively be considered here. They anchored the lives of the three professors in that of a disciplinary community and reinforced the unity of that community.

\section{Lowly Amid a Circle of Great Ones}

The first practice that we will consider was far removed from the commemorative gatherings that the practitioners of a science organised in connection with their remote predecessors: these gatherings were conceived on a magnificent scale and carefully stage-managed, with a high public profile, whereas the dedication of a book involved nothing more than writing down a few words in the privacy of the study. Like the formulation of acknowledgements, the dedication was an unremarkable occurrence, producing a text that by comparison with the actual work was in fact a mere paratext, a 'frame' without much significance, seemingly.

In the dedication, the author paid tribute to a person by naming him (or her) separately at the front of the book and offering him (or her) the book in a brief formula. The person to whom the book was dedicated might still be alive, or might equally already be dead, in which case the book was dedicated to his (or her) memory. He (or she) could stand alone, or might have to share the privilege with others. In 1884, for example, Fredericq dedicated one of the collections he edited of work by his pupils with a plainly-worded allusion to the memory of two recently deceased colleagues: "A la mémoire / de / Johan van Vloten / et / d'Edmond Poullet". Each volume of the large source edition that he dedicated to the history of the Inquisition and that appeared in five volumes between 1889 and 1906 was also dedicated to a fellow-historian (the final one to the memory of Fruin).

The dedication of a book to one or more colleagues, which was also a practice of Te Winkel, was not a self-evident development. For a long time, history books were exclusively dedicated to one or more "dignitaries", such as - if the book was the history of a city - the members of the city council or - if it was the history of a diocese - to the current bishop. For the historian, this dedication to an authority implied an endorsement of his work: the dedication's acceptance by the holder of high office meant that the latter approved of the publication's contents, lent it authority through his own status and ultimately also commended it to the reader. After all, who could doubt the value of a publication that was linked with a person or an authority that was itself elevated beyond all doubt (Verschaffel, 1998: pp. 263-265)? This practice disappeared in the nineteenth century. This disappearance was simultaneously a symptom and a consequence of the growth of the autonomy of historiography. Even in the process of nationalisation that historiography underwent in the nineteenth century, the dedication did not revert to focusing on authority. The fatherland might motivate the modern historian, but he dedicated his

\footnotetext{
${ }^{4} \mathrm{Te}$ Winkel's diary is preserved in the Royal Library in The Hague, no. $77 \mathrm{~F} 7$ (diary entry for 15 April 1874).
} 
work to those whom he held in high esteem in his own guild.

Why this dedication to colleagues, then? Emotional motives doubtless played a role in the choice of recipient: a book was dedicated to a teacher with whom the author was (or had been) closely linked, to a colleague to whom there was a debt of gratitude because of the selfless way in which he had relinquished material, or to a deceased former pupil whose memory was piously honoured. In all these cases, however, there was also another mechanism at work. Just as in the old practice, the author's own name was associated through the dedication with the name of the person to whom the book was dedicated. The modern, nineteenth-century historian linked his name with, for example, the name of Poullet, just as the eighteenth-century historiographer had associated his with, for example, a bishop of Ghent. But whereas the latter had sought affirmation of his work through this association, the former sought entry through his association to the scientific community that was embodied by the historian named in the dedication: dedicating a book to Poullet suggested that the author himself also belonged to the community of the national historian, with its distinctive standards and values.

Rhetoric of humility also belonged here, just as it had done in the eighteenth-century practice (this same modesty also characterised the culture of academic acknowledgments; Wacquet, 2005: pp. 369-370). Fredericq and Te Winkel met their scientific "protectors" with the request that they should accept this very modest token of their deepest admiration. Their dedications were described as respectful and grateful tributes. Thus the dedication became a practice - a commemorative practice - that forged a privileged and almost personal bond with the great masters of the profession, even across the frontiers of death. That was something that indeed required humility.

\section{Circulating Images}

The great masters of the profession: such a company directly evoked the idea of a pantheon. This was a popular idea in the nineteenth century. Among other things, it took the form of an historical genre within cultural nationalism: the heroes of the nation's history-drawn from all periods of that history-were brought together in an image that was intended to convince contemporaries of the might of the nation (see, e.g., Tollebeek \& Verschaffel, 2000 and Bouwers, 2011). In museums - or on their façades - pantheons began to appear in which the geniuses of (national) art could encounter one another. At the same time, harking back to older traditions, pantheons of scholars and professors were assembled in academies and at universities (see, e.g., Ekkart et al., 1991; Van Lennep, 1993 and Oosterheert, 2009).

The origin of the pantheon of professors usually lay in the paintings that were made of professors for an anniversary of the assumption of a chair or for a retirement, and that were presented to them on these occasions (on the portrait of the scholar as a genre, see Jordanova, 2000). This happened to Te Winkel, who was presented with his portrait in 1917 on the occasion of the twenty-fifth anniversary of his professorship. The portrait was done by Thérèse Schwartze, who had acquired considerable fame with her skilled, fashionable portraits of Amsterdam's beau monde and of members of the royal family (Hollema, 2010 and Grever, Van Lith, \& Montijn 2011). Te Winkel was flattered by the painting: he kept it in his home for several years before presenting it to the university in 1920, where it went straight into the academic pantheon, the university's gallery of scholars, which imparted a unity across the ages to Amsterdam's academic community (Bergvelt, Knegtmans, \& Schilder, 2007). By that time, the painting was already more widely known. Immediately after the celebration of the anniversary, Te Winkel had a photograph taken of it which, by way of thanks, he had circulated in large numbers-to colleagues, curators, friends, anyone who had helped pay for the portrait. Perhaps he also took inspiration here from an older custom: from the early seventeenth century, professors at the University of Utrecht would have their portrait painted, and then order copper engravings (or sometimes etchings) made on the basis of this prototype and send them to colleagues.

Te Winkel thus had a reproduction of his portrait circulated. This was not unusual in the world of science, where scholars did not generally wait for paintings - which could then be photographed - in order to distribute their own image. Fredericq went in 1914 to the studio of the Ghent photographer Edmond Sacre to have a portrait photograph made for the Festschrift that would be presented to him several weeks later by the "Société pour le progrès des études philologiques et historiques". But he had previously paid Sacré repeated visits in order to have cartes de visite made. Such cards, with a portrait on them, were the "standard formula" of nineteenth-century photography: they offered a flattering image of the subject, but without originality or unexpected emo-

${ }^{5}$ On Sacré, who was not only a portraitist, but also an urban photographer (of Ghent): Notteboom and Lauwaert 2011. For the quotation: Notteboom and Lauwaert, "Edmond Sacré, fotograaf van Gent" in this book, 41. 
tions - "Nobody has their own vocation, their own personality here." Equally, though, it was these cartes de visite that were distributed and exchanged on a large scale. Their attractiveness lay in the fact that they displayed a photographic portrait.

The circulation of these photographs might enhance the reputation of the person depicted, but also further extend his reputational networks (on these reputational networks, see Craik, 2009). Fredericq knew this. As well as sending his portrait to pupils who asked for it, he also and above all exchanged it with colleagues. In 1896, for example, he sent his photograph to Henry Charles Lea, the gentleman scholar from Philadelphia, with whom he had entered into correspondence in 1888 regarding the work they were both engaged in on the Inquisition. The American was asked to send his own portrait to Ghent, which he duly did. Four years later, Fredericq exchanged his portrait with Salomon Reinach, the French archaeologist and student of comparative literature, with whom he also had political links. The photographs followed the networks: in late 1900, Lea asked Reinach for his portrait. Moreover, this custom was propagated from generation to generation: in 1900 Fredericq's pupil Eugène Hubert also received Lea's portrait, and then sent his own to Philadelphia (Tollebeek, 2004: pp. LXXI, CXVICXVII and 30-33).

In this way, collections of portrait photographs could also be amassed: the historian (or, mutatis mutandis, a practitioner of another discipline in the humanities) would collect the portraits of a whole series of colleagues. Friends could help with this. In 1867, Fruin was given an embryonic collection by the Utrecht physicist F.C. Donders as a present: "I had sent for several photographs of historians from England, in order to give them to you. However, my request was misunderstood. Instead of fairly large photographs of Maull and Polyblank, as I had requested, I was sent visiting cards and informed that Prescott, whom I had also intended to give to you, cannot be obtained in London. In any case, I am now sending you what I received. I think the heads rather powerfully expressive. If possible, better will follow later" (Smit \& Wieringa, 1957: pp. 172-173). The collections could then be shown to visitors. Fruin showed Fredericq part of his collection in Leiden in 1888: photographs of Ranke and Macaulay, but also of the Greek scholar C.G. Cobet and of Donders. One step further was the practice of giving away or exchanging photographs of third parties, as though they were cards produced by Giuseppe Panini: Fruin made Fredericq the gift of a Ranke.

These practices were as unspectacular as dedicating books, but they too were not insignificant. They revealed a desire to admire and also to identify heroes in one's own discipline: heroic figures who served as examples and could form the object of a secular saintly cult. Who, for example, were Fredericq's saints? For him, as for so many others, Ranke was pre-eminent (for the international Ranke celebration, see, e.g., Iggers, 1962). To be sure, Fredericq did not find in him the ardour that he found in romantics such as Jules Michelet or Macaulay, but his admiration remained great. When he went on a tour of the German universities in 1881, he therefore went on a pilgrimage to Ranke in Berlin - another commemorative practice (Nora, 1986). The visit did not last long, but the old historian's appearance made a profound impression: the eighty-six-year-old Ranke, who was still publishing, had become a sort of primogenitor - complete with long white beard - of the modern historical discipline, a mythical figure. But his discipline was also able to shape other heroic figures for Fredericq: Fruin for example, who shared with Ranke the ability to carry on working until a very advanced age, or Louis-Prosper Gachard, the "prince of the archivists".

Ranke, Fruin and Gachard were held in high regard by many modern historians. Their images were therefore coveted. But the same was also true of the lesser gods whose names were associated with the new method or the new "special journals". Fredericq — and with him many others - collected their portraits. They also showed these photographs to their students, but the practice did not stop at that. The photographs were also framed by the recipients, and sometimes inscribed with the year in which they had been received and the age of the subject: "Aet. suae 71, 1896" Fredericq noted on the portrait that he had received from Lea. Finally, the photographs were hung up — next to those already there — on the walls of the room where the students learnt the new techniques and values of the discipline: the historical seminar room in a university-building or the professor's study. In this way, the room in question was further marked (and demarcated) as a place of science.

Such photographic series could also be assembled in a more private manner: not by hanging them together on the walls of the public seminar room or of the semi-public study, but by storing them in an album ${ }^{6}$. Fredericq was among those who did this. When he was presented by his former pupils in Liège with a luxurious photograph album in 1885 on his departure to Ghent, he used the album not just to assemble family and holiday photographs, but also to arrange (at least part of) his collection of portrait photographs of colleagues. The core of

\footnotetext{
${ }^{6}$ For an example from a discipline outside the humanities: Van Bosstraeten (2011), especially 2 and 14-15.
} 
this collection consisted of two double-page spreads of eight portraits each. On the first double page, only German historians were assembled, from Ranke to Gustav Droysen. The second grouped together a more international set, containing among others portraits of his Parisian friend Gabriel Monod and the Leiden professor Pieter Lodewijk Muller.

Fredericq's album was not unique. Te Winkel kept one too, although it was not a luxury photograph album but a simple cahier, stuffed full of portraits of famous writers, painters and scholars (including one of himself), which the professor had cut out of all kinds of journals and prospectuses. In this way, again, a pantheon was created-not a ceremonial pantheon of paintings like that in which Schwartze's portrait would be included, but a private pantheon, cut to size to suit bourgeois admiration, with its enduring need for exempla. Moreover, this miniature pantheon could be supplemented with the cartes de visite that Te Winkel also collected, often gifts received in return after he had sent out his own image. Album images, Te Winkel knew, could reinforce "the less physical image in one's mind".

The world of Fredericq and Te Winkel was one of an indisputably potent visual culture. Images were produced, reproduced and circulated. From the individual painting to the collection of paintings that was the pantheon, from the painting to the photograph, from the portrait sent to the portrait received, from the image to the collection of images in the album, from the series on the wall to the private pantheon: the images migrated from one medium to another, and were multiplied as they went. It was a complex process, in which living and deceased colleagues could be remembered, commemorated and admired, in which the community-literally—was depicted and in which the examples of the discipline displayed in the album could further reinforce the bonds that held that community together.

\section{A Chain of Tribute Events}

Other commemorative practices also played a role in this community-building process. They were practices in which the element of spectacle was far more explicitly present than was the case with the dedication of a book or the circulation and collection of photographs. This was true in particular for what were usually referred to as "tribute events": the large gatherings at which a person was honoured, usually on the occasion of a birthday, an anniversary or, if it was a professor, some other important moment from his academic career. Tribute events marked these moments. They were rituals which were performed according to a template that allowed little variation.

Such events became important tools in the mise-en-scène of the modern humanities disciplines, not least because of their frequency: the tribute culture of the historians, art historians, practitioners of literary studies and their colleagues from the other humanities was no less flourishing in the late nineteenth and early twentieth centuries than that of writers and artists. There really was a chain of tribute events. For example, Belgium's historians gathered in large numbers for the first time at the "Kurthfeest" that was organised in Liège in 1898. This was followed by a series of lesser events, until another spectacular event took place in 1912: the "Pirennefeest" in Brussels. The nature of these two major events was somewhat different, however. In Liège, the primary focus was on the fact that the first seminar for historians in Belgium had been established a quarter of a century earlier; the man who had introduced that institution, the Liège professor Godefroid Kurth, was lost from view somewhat in the process. In Brussels, a personality cult was very much in evidence: the spotlights were trained on Fredericq's collega proximus at Ghent, Henri Pirenne, the occasion being both the twenty-fifth anniversary of his professorship and the completion of the fourth volume of his popular Histoire de Belgique. The Dutch historians, meanwhile, organised two events to do with Fruin: in 1885, on the occasion of his twenty-fifth anniversary as a professor, and in 1894, on his departure from the chair.

The organisation of these and similar events can be compared with that of a military campaign, not least in view of its precision. Control lay with an organising committee, with a clear hierarchy and a strict allocation of tasks. The committee was chaired by the closest colleague or oldest pupil of the subject of celebration. He was an established professor, while the function of secretary was filled by a young - in the cited cases - historian, who was still at the bottom of the ladder. The role of this committee was to decide, in what could be a long series of meetings, on the design of the event, and put those decisions into practice. An effective tribute committee needed to be formed, circulars had to be sent out to announce the planned gathering, the necessary funds needed to be collected for the purchase of a suitable gift. But countless other preparations also needed to be made: the 
allocation of roles for the speeches and toasts, the seating in the hall, deciding on and printing up the menu for the banquet, and so on.

The course of such events varied, but they were usually divided into two parts, each with its own character: an academic session and a banquet or dinner. The academic session usually took place in a university auditorium (or in the Academy building). This befitted its formal nature. The core of the academic session consisted of a series of addresses (including the valedictory speech of a retiring professor if this was the subject of the celebration), with no set pattern for the sequence of speakers. Each speaker - the chairman, a former pupil, a student, a representative of the academic authorities, a colleague, a foreign colleague, etcetera - had his own rhetoric approach. But this did not exclude traditions: the major ceremonial orations, for example, could be traced back to the éloges pronounced by newly inducted members of the "Académie française" about their predecessors (see Fumaroli, 1986). The range of content could also be considerable: the speeches obviously dealt with the subject of the event, his career, writings and achievements, but in the moral portrait that was outlined in the process - more than on other occasions - the overall ethics of the science (at least as advocated by the speaker) were made explicit.

The public at such an academic session consisted in the first place of colleagues of the person in question - colleagues, moreover, of different stripes. This was important: the fact that both Catholic and liberal historians were presented at the "Kurthfeest", barely fifteen years after the School War (the ideological dispute over the organisation and financing of education which had divided Belgium), demonstrated that the historian's professional identity could surmount ideological boundaries. But the audience consisted of more than colleagues. These gatherings may have had a formal character, but they were not private occasions, as was strikingly apparent from the presence of politicians (who might also have a seat on the tribute committee). In this respect too, differences persisted, incidentally: at the celebration for Fruin in 1885 there was no political representation, whereas a large number of politicians were present at the "Pirennefeest" (Keymeulen \& Tollebeek, 2011: pp. 39-41). For the historians themselves — at such occasions "cultural diplomats" (Rigney, 2011: p. 89)—-the significance of this presence was unmistakable. It illustrated the social importance and prestige of their profession: in a modern nation, there had to be a place for a modern historical science. Conversely, the politicians gained scientific kudos from their presence. This of course was not just true of history or of the humanities. In 1892, at a celebration at the Sorbonne of the seventieth birthday of Louis Pasteur, Sadi Carnot, president of the Republic, supported the old and by now frail biologist and led him to his armchair. It became a powerful image (BenAmos, 2000: p. 238).

But it was not just politicians who gained distinction from their presence among the subject's colleagues. The attendance list also usually included his family members. For example, in 1912 Pirenne's academic session was attended by his wife, his four sons, his mother, his sisters and his brothers-in-law, making it clear that the interwoven nature of public and private that so strongly characterised the university as a "habitat" (see Van Berkel, 2009: pp. 15 and 22-27) was also typical of the commemorative practices in its midst. Remembering and commemorating also belonged to the domestic sphere.

This was even more apparent at the second part of the event, which usually consisted of a banquet or dinner, possibly after a reception. The university building was now exchanged for a restaurant, where a large numbers of guests might be present: at the Manifestation Kurth, dinner for 175 was served in the salons of a Liège hotel. But this part might also be smaller in scale and more private. In 1885, Fruin gave a select company a "beautiful Gargantuan dinner" in the spacious confectioner's premises next door to his own home. Such dinners had a more informal character than the academic sessions that preceded them. That informality was-particularly in small companies - reinforced by the presence of people who did not belong to the circle of colleagues. The "Gargantuan dinner" in 1885 was also attended by the daughter of Fruin's recently deceased Leiden colleague R.P.A. Dozy, an orientalist. At the dinner organised at the event in honour of Fredericq in 1904 by the Brussels professor Léon Vanderkindere, president of the "Société pour le progrès des études philologiques et historiques", at his mansion in Uccle (near Brussels), the host's wife and two daughters were among the guests.

In this atmosphere of conviviality (and intimacy), speeches were not given, but toasts were usually proposed. These might be very poignant. But the dinners might also lead to high spirits: at Fruin's dinner, Fredericq sang for the guests. There was no discussion here of the things that usually occupied the historians who attended: the collection of documents, source criticism or the obstacles that always made it difficult for them to complete their research. These occasions were about sealing in friendship the ties that had already been forged during the aca- 
demic session. The events encouraged socialising among the historians present.

\section{Conviviality and Charisma}

When Kurth, Pirenne or Fruin was the subject of celebration, the occasion was clearly about more than confirming the existing hierarchy and power relations in the discipline or a tool for displaying the discipline's social significance. It was about practices in which formal and informal, academic and domestic behaviour were intertwined around the contemporary standard-bearers of the science. But what was the deeper significance of these practices? Were they ultimately anything more than the first-class funerals to which Fredericq referred at the Manifestation Vanderkindere in Brussels in 1902, melancholy ceremonies at which professors approaching retirement were given a preliminary send-off? Or even artificial displays, whose grand gestures seemed pathetic at a distance, whose emotions were not always as deep or as sincere as they looked, and whose eulogies were usually overblown? Those involved were themselves capable of playing down the significance of the festive events. The unabating enthusiasm for celebrations and tributes was turning him and his acquaintances, Fredericq perceived, into big children, offering their applause time and again for what in the end was mainly rhetoric.

How then, given all this scepticism about the culture of tribute events, should we interpret the fact that so many continued to advocate them passionately? Why did they think these events so important? The answer lies in the belief that these gatherings, like the dedications in books and the albums of portraits of colleagues, could contribute to further community-building. That belief applied not just to the events within one's own scientific community, but also - more generally - to its academic culture. Te Winkel, who also devoted considerable attention to the external symbols of the university community (such as the gown), repeatedly explained that the professors formed a collective in which respect for one another's scientific qualities was accompanied by sentiments of true friendship. For the bachelor Fruin, the friendships that were cultivated in the world of Leiden's professors could give rise to "more than brotherly love". For Fredericq, another bachelor, who was unwilling to miss a single meeting of the Faculty or of the Academic Council (and regarded the gown as the only uniform that was elevated above any form of mockery), the university was a family.

A family - this also turns out to be a crucial concept for understanding the events celebrating colleagues: they were regarded as family celebrations. This was openly expressed. Kurth referred in his speech at the end of the event of 1898 to a fête de famille (which the minister who attended had, in his view, also turned into a fête nationale). In 1912, Fritz Arnheim, the German translator of the Histoire de Belgique, emphatically took up the term "family celebration" at the event in honour of Pirenne: "I say it expressly: Familienfest. For this is a celebration of the great and illustrious family of Belgian historians, which today pays itself honour by celebrating one of its members, the famous author of the Histoire de Belgique" (Manifestation Henri Pirenne, 1912: p. 50).

Describing the events as "family celebrations" presupposed that such a family-of historians, for example, or of practitioners of literary studies, archaeologists or musicologists-already existed, and that that family merely needed to foregather at the appointed place and the appointed time. The reality was more complex: the community of colleagues, which had already taken shape on the basis of a more or less shared method, the emphasis on discipline, the development of its own pantheon and other elements, was further shaped at these events. They were not simply a confirmation of something that already existed. They were practices by which the reality was further constructed: they forged a corporate spirit. That made the actual presence of all-the element of copresence (Rigney, 2011: pp. 78-79) - at these special occasions essential. A conviviality came into play that was not part of the other commemorative practices, or only to a far lesser extent. In that conviviality, a bridge was also built between the local and the global. The events were (usually) organised at the specific place with which the subject was closely associated - Kurth was a man of Liège, Fruin was a professor from Leiden — but the colleagues who were present came from everywhere, and hence from nowhere. The scientific community, which in principle was without location, took shape at and through concrete, localised gatherings.

The community-building role of the festive events was also apparent from another element: the gift that was presented to the subject of the celebration. This might be a painted portrait or a bust, as was the case for Te Winkel. It might also be something more original, as was the case for Fruin. The "grateful admirers of his work" had collected sufficient funds in 1885 to present him with a portfolio of over a hundred historical prints, stored in a cabinet made specially for the purpose (Haak \& Vogelaar, 2001 and Veldman, 2010). Nine years later, in 1894, Fruin was given what Fredericq would receive in 1904 and Pirenne in 1926: a "classic" Festschrift, consisting of a large collection of studies, written by colleagues and pupils, each of whom had made a contribution in their own specialist field. The tradition of the Festschrift was still young at that time. The first examples of 
the genre had appeared in Germany in the 1860s and 1870s (including the Commentationes in honour of Theodor Mommsen published in 1877). By around 1900, however, the custom was already widespread in both the humanities and the social sciences (on this genre, see Waquet, 2006a; Waquet, 2006b). The unity of content (and style) of such Mélanges was often very slight; usually, the only unity they had was the fact that all the authors stood in some relationship to the recipient. It was not by chance that the contributions in the Mélanges for Pirenne were simply arranged alphabetically by author's name, from Ashley to Vincent. But this negative judgement, which also gave the genre a somewhat poor reputation over time (a book full of unappealing items), could also be reinterpreted in a positive light: the Mélanges created a community around the recipient.

That recipient could become a father figure. In the first place, he could be a father to his assistants and promoti, with whom he formed an extended family (for the expression "extended family", see Kelley, 2003: pp. 174-175). He acted as a patron, "placing" and "launching the careers" of his pupils. Equally, though, he sought to provide consolation if someone became depressed, or to provide financial support when someone ran short of money. The father-professor might even undertake to care for the relatives of one of his assistants if that proved necessary. In order to maintain such a relationship, a wide range of values and emotions were important. The assistants and promoti were expected above all to display loyalty, but also affection and respect. The father-professor was expected to offer support and protection. It was a mutual commitment.

But the recipient might also become a father in a wider sense: he might become the father of a discipline, the "father of modern Dutch historiography" for example (and hence acquire a central place in the pantheon of that discipline $)^{7}$. There had always been such fathers: for example, the historians had always referred to Herodotus and Thucydides. When the science took on national colouring in the nineteenth century, the father figures also became national figures, who could also satisfy national pride. In historiography, it was thus mainly the authors of the great national syntheses that became eminent: František Palacký for the Czechs, for example, or Georg Zacharias Forsman in Finland (Berger, 2011 and Tollebeek, 2012). Here too, though, different variants persisted. Around 1900, Fruin was regarded as the father of Dutch historiography, because he was seen as the ideal embodiment of the epistemic virtues that were held to characterise modern historical science. Later he would become more of a primogenitor, a virtually mythical figure who stood at the origins of the (often teleologically narrated) account of the history of Dutch historical science as a discipline (on disciplinary history accounts, see Graham, Lepenies, \& Weingart, 1983; see also Biondì, 2011). Among the Belgian historians, Kurth was regarded as a father around 1900. Unlike in Fruin's case, though, this did not mean that he was presented as a model to imitate. The Liège professor was mainly honoured as a predecessor, as the man who had introduced the new scientific practice of the seminar into his country.

The fatherhood of a discipline could thus be interpreted in different ways. In each case, however, it was an important element of the academic commemorative culture, closely bound up in its origin with the tribute events. It was an element that also revealed the extent to which the cult of charismatic figures remained important even in the rational atmosphere of the fast-growing research university (see the major study by Clark, 2006). Here the modern cult of the academic personality was developed, precisely at the time when Europe's cultural elite were taking up Jacob Burckhardt's Die Kultur der Renaissance in Italien, published in 1860, and reading the pages in that work about the genesis of modern fame ("eine neue Art von Geltung nach außen")

\section{Dealing with the Dead}

At the same time, an interest in the dead was developing in the modern disciplines - not the great deceased figures from the remote past (the likes of Copernicus and Stevin), whose anniversaries were celebrated, but recently departed colleagues. The importance given to the discipline's "own" dead and to their actual death was linked to two developments. On the one hand there was the growing mutual involvement of colleagues, which meant, for example, that historical science increasingly came to be regarded as a family affair. And although that family grew as the science increased in scale, and members were no longer acquainted with every nephew and niece, a death in the family was always an occurrence to be mourned. On the other hand, there was the desire to anchor the new disciplines in the past: although they were presented as the result of a progressive movement, which broke with traditions and conventions, they were not presented as an ahistorical phenomenon. They were

\footnotetext{
${ }^{7}$ For what follows: Paul (2010); Paul (2011) and Paul (2011). For Fruin, see also Wesseling, 1988.

${ }^{8}$ Burckhardt discussed modern fame in Renaissance Italy in the second chapter ("Entwicklung des Individuums") of Die Kultur. For the context in which this book was originally read, see Gossman (2000).
} 
formed, it was claimed, by a number of pioneers in the recent past, pioneers who had continued to work to an advanced age and should now be (now deserved to be) commemorated. This response to the dead of the discipline also reinforced the sense of community.

The concern for the dead was displayed in the development of new practices, including the attendance of the funeral of deceased colleagues. Such funerals were capable of developing in the course of the nineteenth century into events with a strong element of spectacle. This was true in particular of the state funerals that were given in France, not just to a number of statesmen and writers, but also to a number of practitioners of science. The funerals of the physiologist Claude Bernard, of Pasteur and later of the bacteriologist Emile Roux were civic festivals, at which the practitioner of science, quite apart from his professional qualities, was assigned a moral authority in society and in the political sphere (Ben-Amos, 2000: pp. 235-240).

But even without such a mark of honour, the funerals of academics could turn into gatherings at which not just the (actual) family of the deceased was present, but also various colleagues. In 1889, Fredericq interrupted his visit to the Paris world exhibition for the funeral of Numa Denis Fustel de Coulanges. He discovered that he was not the only member of the guild there: an extensive company of historians attended the ceremony to see how "France laid its latest great historiographer in the grave" (for Fustel de Coulanges, as an introduction to nineteenth-century historiography: Hartog, 2001). The same was true of Fruin's funeral ten years later: there were many mourners and many colleagues. However, these were foreign celebrities. There were also the national funerals, which Fredericq attended as faithfully as the organised tribute events.

A second commemorative practice relating to the dead of the discipline was the writing of colleagues' obituaries. These obituaries did not just follow on from an earlier practice: the oraisons funebbres that formed a fixed element of humanistic discourse (see inter al. Bonnet, 1986; more generally: Bonnet, 1998). They also fitted in with a broader set of textual genres that gained in popularity from the nineteenth century onwards, including academic eulogies, compendia of academic lives, biographies and autobiographies of individual practitioners of science and advice manuals for aspiring practitioners. What all these textual genres have in common (alongside their differences) is the fact that their focus was on the life (the subjectivity) of the practitioner precisely at a time when the literary conventions of scientific publications were themselves increasingly requiring the personality of the author and the circumstances in which the research was conducted to vanish from the text (Daston \& Galison, 2010: p. 217). The surprising success of the historical scientific biography in the nineteenth centuryin a period when the cumulative nature of scientific knowledge was thus being stressed - points in the same direction (see Welvaert, 2002).

The obituary was a demanding genre, not least because the author was also expected to provide a portrait of the deceased's personality. However, the extent to which this was done varied; as a genre, the obituary had a number of different variants. The first, most direct variant was the funeral oration. In the oral culture that nineteenth-century society still remained to a large extent, "speaking fair words by the grave" was an important part of the funeral, and it was no different when the listeners partially consisted of practitioners of science.

The second variant of the obituary also retained an oral character, but was practised in a different, exclusively scientific, context: the spoken commemoration, a practice that Fredericq, for example, also enjoyed displaying his mastery of. The Ghent professor commemorated deceased colleagues-such as Poullet in 1882 - at the start of his cours pratique, the series of discussion sessions in which he introduced a small group of students to historical research. Such commemorations were usually short, improvised communications: the identification of the deceased, an overall assessment of his personality or oeuvre, a listing of his works - virtually a biographical notice. On one occasion only — when close personal ties had existed with the deceased — were the students given a longer speech: "a heart-felt tribute" in memory of a friend.

The obituary proper was a written text. It was generally written for a readership of colleagues, although this concept could be somewhat stretched for the occasion. Fredericq for instance, definitely an aficionado of these obituaries, published them in a journal such as the Revue de l'Instruction publique de Belgique, for an audience of professors and teachers, of historians and archivists, of specialists and assertive "autodidacts", who practised history with a passion that he relished. But he also wrote obituaries-including of colleagues-for a far less exclusive forum such as Het Volksbelang, the weekly paper of Ghent's liberal Flemish nationalists, of which he was the chief editor for many years.

These obituaries, Fredericq knew, were an important tool in scientific commemorative politics. Writing them could carry a great deal of prestige and could therefore be the object of controversy. When the Leiden professor Matthias de Vries died in 1892, Te Winkel therefore immediately appointed himself as his obituary-writer. For 
De Vries, like his colleague Fruin, was regarded as a father figure: he was, it was claimed, the father of the modern study of Dutch literature, because of the enthusiasm that was so characteristic of him, but above all because of his scientific merits as an editor of Middle Dutch texts and as a philologist. By immediately putting himself forward as his obituary-writer, Te Winkel created continuity and instantly made his own position clear: he was the son who commemorated the father (and hence also believed he was entitled to the father's legacy, De Vries' vacant chair at Leiden). In this way, there also arose in the humanities professional genealogies, which could contribute to further community-building.

A fourth and final variant of the obituary was the obituary section that appeared in the new journals such as - again for historians - the French Revue historique. In such a section, which might sometimes form part of a broader chronicle, deceased colleagues were briefly remembered. The conciseness required by both the section and the chronicle did not permit "heart-felt tributes" to be given in these places. At the same time, though, they had a considerable power of suggestion. The mere listing of the colleagues who had died in the past year and the "bare" indication of their position or status evoked the image of a host of workers single-mindedly devoted to reclaiming the past: scholarly war veterans.

\section{A Community of Memories}

The obituaries formed the closing piece of a mixed set of commemorative practices that developed in the modern humanities disciplines and that also included the dedication of work to living and deceased colleagues, the exchanging and collecting of portrait photographs of admired colleagues, an extensive culture of tribute events around father figures and the attendance of funerals. All these practices were widespread. They all testify to the desire not only to find the professional community on a scientific method and on the strict requirements of loyalty and discipline, but also to give it an intense sense of interconnectedness. Precisely in the humanities, where discipline-building was rendered difficult by the lack of a recognisable theoretical project and methodological unanimity and by the contesting of the academic monopoly and the current intellectual and moral values, it was important to reinforce this sense of interconnectedness not only at ceremonial, highly ritualised occasions, but also in more everyday gestures.

This development made the world of the modern humanities around 1900 an emotionally charged one. This did not mean that it was shot through with strong passions. The picture that comes to mind is rather that of Fruin's tears. At the festive event that was organised for him in 1885, respectability and emotion went hand in hand; it was not by chance that Fredericq described the gathering as a simple et touchante cérémonie (Fredericq, 1899: p. 172). Impressive words were spoken in Leiden on that occasion, about "love of truth" for example, but emotion was also displayed: "Fruin simply wept", noted by Fredericq.

Fruin, Fredericq, Te Winkel and their colleagues in the humanities lived a life full of memories. They had the optimism of the avant-garde: the sense of representing something new, the joy at what had been achieved, and the reputation of being modern. But this scholarly avant-garde continually displayed the need for a commemorative culture. That culture was pervaded not by optimism, but by melancholy and nostalgia. The dedications to inspirational figures who were no longer there, the portrait photographs of absent colleagues, the pilgrimage to a fading shadow, the tribute events that always involved saying farewell, the funerals and the obituaries: it also constantly made the practice of the humanities a sentimental journey through theatres of a past that was over and old places of remembrance. That sentimental journey also helped historians and archaeologists, art historians and theologians to find a place in the changing world of the fin de siècle, a stable point where they themselves could go in search of the lost worlds that they sought to reconstruct in their work and whose loss they often regretted.

As a result of their strong commemorative culture, the young humanities became marked by a sadness thatat a more personal level-also manifested itself in the life stories of the aged Fruin, Fredericq and Te Winkel. That sadness could sometimes acquire considerable emotional intensity. But its effect was paradoxical: it helped - with all its remembrance and its recollection, and all its memories - to form and strengthen the humanities disciplines in a fundamental manner. Fruin's tears also foretold the future.

In that future - and right up to the present day - commemorative practices continued to play a meaningful role in disciplinary community-building and community-strengthening. There is an unmistakable continuity here. However, the ongoing expansion of scientific endeavour and the associated "anonymisation" of disciplines, including those in the humanities, lessened the impact of these commemorative practices again. Although books 
continued to be dedicated to colleagues, portraits were no longer exchanged, organised events lost their expressive potency, and scholars' relationship with the dead became more detached again. These things became rituals that only seemed to appeal to the older generations: testimonials to a culture that appeared to be losing its vitality, despite its survival.

This state of affairs raised one final question: did the academic culture of remembrance develop everywhere in Europe at the same time and in the same way, or were there national (or even regional) differences? The examples from Belgium and the Netherlands used here had their heyday around 1900. To all appearances, the commemorative practices took shape in Germany earlier. The genre of the Festschrift, for example, originated in the German universities, and was then taken up in France, Italy and other European countries. In Great Britain, however, it was largely non-existent, even around 1900 (Waquet, 2006a: pp. 103-104). Yet, such national differences should not be allowed to disguise the fact that a process of internationalisation was also underway at precisely this period, around 1900. The first of the major five-yearly congresses of historians, for example, was organised in Paris in the summer of 1900 (Erdmann, 1987). This turned the commemorative practices too into international phenomena: the exchanging of photographs, the grand functions, and the obituaries in the specialist journals reflected an international sociability. As a result, the academic remembrance culture also assumed a more homogeneous form. It became more recognisable.

\section{References}

150 Jahre Geschichtsforschung im Spiegel der Historischen Zeitschrift (2009). Special Edition of Historische Zeitschrift (Vol. 289, No. 1).

Abir-Am, P. G. (Ed.) (1998). La mise en mémoire de la science. Pour une ethnographie historique des rites commémoratifs. Paris: Editions des Archives Contemporaines.

Abir-Am, P. G., \& Elliott, C. A. (Eds.) (1999). Commemorative Practices in Science: Historical Perspectives on the Politics of Collective Memory. Special Edition Osiris. A Research Journal Devoted to the History of Science and Its Cultural Influences, 2nd Series, 14.

Abma, R. (2011). Over de grenzen van disciplines. Plaatsbepaling van de sociale wetenschappen. Nijmegen: Vantilt.

Ben-Amos, A. (2000). Funerals, Politics, and Memory in Modern France, 1789-1996. Oxford: Oxford University Press. http://dx.doi.org/10.1093/acprof:oso/9780198203285.001.0001

Berger, S. (2011). Fathers' and Their Fate in Modern European National Historiographies. In H. Paul (Ed.), Fathers of History: Genealogies of the Historical Discipline (Vol. 59-60, pp. 231-250). Special Supplement in Storia della Storiografia.

Bergvelt, E., Knegtmans, P. J., \& Schilder, M. (Eds.) (2007). Kleurrijke professoren. 375 jaar portretkunst in de collectie van de Universiteit van Amsterdam. Amsterdam: Amsterdam University Press.

Billen, C., \& Boone, M. (2011). Pirenne in Brussels Before 1930: Guillaume des Marez and the Relationship between a Master and His Student. In M. Boone, C. Billen, \& S. Keymeulen (Eds.), Henri Pirenne (1862-1935): A Belgian Historian and the Development of Social and Historical Sciences (Vol. 41, pp. 459-485). Special Edition of Belgisch Tijdschrift voor Nieuwste Geschiedenis/Revue belge d'Histoire contemporaine.

Biondì, D. (Ed.) (2011). What Philosophers of History Can Do with The Self-Image of the Historical Discipline (Vol. 59-60, pp. 150-223). Special Supplement in Storia della Storiografia.

Bod, R. (2010). De vergeten wetenschappen. Een geschiedenis van de humaniora. Amsterdam: Bert Bakker.

Bonnet, J.-C. (1986). Les morts illustres: oraison funèbre, éloge académique, nécrologie. In P. Nora (Ed.), Les lieux de mémoire, Part 2: La Nation (Vol. 3, pp. 217-241). Paris: Gallimard.

Bonnet, J.-C. (1998). Naissance du panthéon. Essai sur le culte des grands hommes. Paris: Fayard.

Bouwers, E. G. (2011). Public Pantheons in Revolutionary Europe: Comparing Cultures of Remembrance, c. 1790-1840. Basingstoke: Palgrave Macmillan. http://dx.doi.org/10.1057/9780230360983

Burke, P. (2010). Co-Memorations: Performing the Past. In K. Tilmans, F. van Vree, \& J. Winter (Eds.), Performing the Past: Memory, History, and Identity in Modern Europe (pp. 105-118). Amsterdam: Amsterdam University Press.

Clark, W. (2006). Academic Charisma and the Origins of the Research University. Chicago-London: The University of Chicago Press.

Collini, S. (2012). The Character of the Humanities. In S. Collini (Ed.), What Are Universities for? (pp. 61-85). London: Penguin Books.

Craik, K. H. (2009). Reputation: A Network Interpretation. Oxford: Oxford University Press.

Daston, L., \& Galison. P. (2010). Objectivity. New York: Zone Books.

Dorsman, L. (2011). Van OB 1815 naar WHW 1985: Van "geleerde stand" naar "zelfstandige beoefening der wetenschap". 
Het hoger onderwijs en de disciplines. In L. Dorsman, \& P. J. Knegtmans (Eds.), Van Lectio tot PowerPoint. Over de geschiedenis van het onderwijs aan de Nederlandse universiteiten (pp. 115-128). Hilversum: Verloren.

Ekkart, R. E. O. et al. (1991). Knappe koppen. Vier eeuwen Nederlands professorenportret. Utrecht-Zutphen: Centraal Museum.

Erdmann, K. D. (1987). Die Ökumene der Historiker. Geschichte der Internationalen Historikerkongresse und des Comité International des Sciences Historiques. Göttingen: Vandenhoeck \& Ruprecht.

Eskildsen, K. R. (2008). Leopold Ranke's Archival Turn: Location and Evidence in Modern Historiography. Modern Intellectual History, 5, 425-453. http://dx.doi.org/10.1017/S1479244308001753

Fredericq, P. (1899). L'enseignement supérieur de l'histoire. Notes et impressions de voyage. Allemagne-France-EcosseAngleterre-Hollande-Belgique. Ghent-Paris: J. Vuylsteke-Félix Alcan.

Fumaroli, M. (1986). La Coupole. In P. Nora (Ed.), Les lieux de mémoire, Part 2: La Nation (Vol. 3, pp. 321-388). Paris: Gallimard.

Gossman, L. (2000). Basel in the Age of Burckhardt: A Study in Unseasonable Ideas. Chicago-London: The University of Chicago Press.

Graham, L. R., Lepenies, W., \& Weingart, P. (Eds.) (1983). Functions and Uses of Disciplinary Histories. Dordrecht-Boston-Lancaster: Kluwer. http://dx.doi.org/10.1007/978-94-009-7035-9

Grever, T., van Lith, W., \& Montijn, I. (2011). Thérèse Schwartze 1851-1918. De Nederlandse fine fleur geportretteerd. Zwolle: W Books.

Haak, P., \& Vogelaar, C. (2001). Het kabinet van Robert Fruin. Een 19de eeuwse kijk op de vaderlandse geschiedenis. Leiden: Stedelijk Museum.

Hartog, F. (2001). Le XIXe siècle et l'histoire. Le cas Fustel de Coulanges. Paris: Presses Universitaires de France.

Hollema, C. (2010). Thérèse Schwartze (1851-1918). Haar klant was koning. Zutphen: Walburg Pers.

Iggers, G. G. (1962). The Image of Ranke in German and American Historical Thought. History and Theory: Studies in the Philosophy of History, 3, 17-40. http://dx.doi.org/10.2307/2504333

Johannes, G.-J. (2011). "Nationale filologieën" en het historisch onderzoek naar disciplinevorming in de geesteswetenschappen. Een verkenning. Studium. Tijdschrift voor Wetenschaps-en Universiteitsgeschiedenis/Revue d'Histoire des Sciences et des Universités, 4, 31-46.

Jordanova, L. (2000). Defining Features: Scientific and Medical Portraits 1660-2000. London: Reaktion Books.

Kelley, D. R. (2003). Fortunes of History: Historical Inquiry from Herder to Huizinga. New Haven-London: Yale University Press.

Keymeulen, S., \& Tollebeek, J. (2011). Henri Pirenne, Historian: A Life in Pictures. Leuven: Leuven University Press.

Manifestation en l'honneur de M. le professeur Henri Pirenne. Bruxelles 12 mai 1912 (Mons 1912).

Møller Jørgensen, C. (2012). Scholarly Communication with a Political Impetus: National Historical Journals. In I. Porciani, \& J. Tollebeek (Eds.), Setting the Standards: Institutions, Networks and Communities of National Historiography (pp. 70-88). Basingstoke: Palgrave Macmillan.

Nora, O. (1986). La visite au grand écrivain. In P. Nora (Ed.), Les lieux de mémoire, Part 2: La Nation (Vol. 3, pp. 563-587). Paris: Gallimard.

Notteboom, B., \& Lauwaert, D. (Eds.) (2011). Edmond Sacré. Portret van een stad. Gent, 1851-1921. Brussels-Ghent: Mercatorfonds-STAM.

Oosterheert, J. (2009). In vol ornaat. Vier eeuwen Groningse senaatsgalerij. Groningen: Barkhuis Publishing.

Paul, H. (2010). "De Hollandsche meester der streng-analytischen methode". Robert Fruin als vader van de Nederlandse geschiedwetenschap. In H. Paul, \& H. te Velde (Eds.), Het vaderlandse verleden. Robert Fruin en de Nederlandse geschiedenis (pp. 221-248). Amsterdam: Bert Bakker.

Paul, H. (2011). Voorbeeld en voorganger. Robert Fruin en Godefroid Kurth als vaders van de geschiedwetenschap. $B i-$ jdragen en Mededelingen betreffende de Geschiedenis der Nederlanden/The Low Countries Historical Review, 126, 30-53.

Paul, H. (Ed.) (2011). Fathers of History: Genealogies of the Historical Discipline. Special Supplement in Storia della Storiografia, 59-60, 224-293.

Petit, A. (1998). La commémoration de l'héritage scientifique dans le positivisme: théories et pratiques. In P. G. Abir-Am (Ed.), La mise en mémoire de la science. Pour une ethnographie historique des rites commémoratifs (pp. 159-187). Paris: Editions des Archives Contemporaines.

Rigney, A. (2011). Embodied communities: commemorating Robert Burns, 1859. Representations, 115, 71-101. http://dx.doi.org/10.1525/rep.2011.115.1.71 
Smit, H. J., \& Wieringa, W. J. (Eds.) (1957). Correspondentie van Robert Fruin 1845-1899. Groningen-Jakarta: J.B. Wolters.

Tollebeek, J. (2004). Writing the Inquisition in Europe and America: The Correspondence between Henry Charles Lea and Paul Fredericq. Brussels: Royal Historical Commission.

Tollebeek, J. (2008). Fredericq \& Zonen. Een antropologie van de moderne geschiedwetenschap. Amsterdam: Bert Bakker.

Tollebeek, J. (2010). Een wetenschap van kleine gebaren. Historiografische praktijken in de late negentiende eeuw. In H. Paul, \& H. te Velde (Eds.), Het vaderlandse verleden. Robert Fruin en de Nederlandse geschiedenis (pp. 17-37). Amsterdam: Bert Bakker.

Tollebeek, J. (2011). Men of Character: The Emergence of the Modern Humanities. Wassenaar: Netherlands Institute for Advanced Study in the Humanities and Social Sciences.

Tollebeek, J. (2012). Exegi Monumentum: The Great Syntheses of National History. In I. Porciani, \& J. Tollebeek (Eds.), Setting the Standards: Institutions, Networks and Communities of National Historiography (pp. 105-129). Basingstoke: Palgrave Macmillan.

Tollebeek, J., \& Verschaffel, T. (2000). “A Profitable Company”. Het pantheon als historisch genre in het negentiende-eeuwse België. Bijdragen en Mededelingen betreffende de Geschiedenis der Nederlanden, 115, 223-243.

Torstendahl, R. (2010). From All-round to Professional Education: How Young Historians Became Members of an Academic Community in the Nineteenth Century. Een goede historicus? Negentiende-eeuwse idealen en praktijken, special edition Leidschrift, 25, 17-31.

Van Berkel, K. (2009). Academisch leven. Over geschiedenis, karakter en veerkracht van de Nederlandse universiteit. Amsterdam: Bert Bakker.

Van Bosstraeten, T. (2011). Dogs and Coca-Cola. Commemorative Practices as Part of Laboratory Culture at the Heymans Institute Ghent, 1902-1970. Centaurus, 53, 1-30. http://dx.doi.org/10.1111/j.1600-0498.2010.00204.x

Van Lennep, J. (1993). Les bustes de l'Académie royale de Belgique. Histoire et catalogue raisonné précédés d'un essai Le portrait sculpté depuis la Renaissance. Brussels: Académie royale des Sciences, des Lettres et des Beaux-Arts de Belgique.

Veldman, I. M. (2010). De kast van Fruin. Prenten als historische bron. In H. Paul, \& H. te Velde (Eds.), Het vaderlandse verleden. Robert Fruin en de Nederlandse geschiedenis (pp. 82-107). Amsterdam: Bert Bakker.

Verschaffel, T. (1998). De hoed en de hond. Geschiedschrijving in de Zuidelijke Nederlanden 1715-1794. Hilversum: Verloren.

Waquet, F. (2005). Acknowledgments: Instructions for Use. Modern Intellectual History, 2, 361-385. http://dx.doi.org/10.1017/S147924430500048X

Waquet, F. (2006a). Les “mélanges": Honneur et gratitude dans l'Université contemporaine. Revue d'Histoire Moderne et Contemporaine, 53, 100-121.

Waquet, F. (2006b). Academic Homage and Intellectual Genealogy: The Collège de France Inaugural Lectures, $1949-2003$. History of Universities, 21, 202-227.

Wegener, D. (2011). Wetenschapsgeschiedenis op lange termijn: flexibiliteit en fragiliteit van disciplines. Studium. Tijdschrift voor Wetenschaps-en Universiteitsgeschiedenis/Revue d'Histoire des Sciences et des Universités, 4, 16-30.

Welvaert, A. (2002). De herö̈ek van de waarheidszoeker. Belgische wetenschapsbiografieën 1870-1930. Leuven: unpublished master thesis.

Wesseling, H. L. (1988). Robert Fruin, De geschiedenis van een reputatie. Jaarboek van de Maatschappij der Nederlandse Letterkunde te Leiden 1986-1987, 1988, 3-18.

Zwick, J. (1997). Akademische Erinnerungskultur, Wissenschaftsgeschichte und Rhetorik im 19. Jahrhundert. Über Emil Du Bois-Reymond als Festredner. Scientia Poetica, 1, 120-139. 